\title{
Analysis on Income Status between Urban and Rural Areas in Shijiazhuang City and Developing Countermeasures
}

\author{
Siyuan Deng \\ Shijiazhuang Economic College, \\ Shijiazhuang, China
}

\begin{abstract}
This paper analyzes the changes of the income growth rate and per capita income gap between urban and rural residents in Shijiazhuang City. The gap of absolute income value between urban and rural residents in Shijiazhuang is increasing, and urban residents' income grows faster; expound the historical trajectory of the income gap between urban and rural residents in Shijiazhuang city; Compare the income gap during Shijiazhuang city and Hebei Province as well as the nation. The income gap between urban and rural residents in Hebei province is shrinking after 2007, and the income gap between urban and rural residents in Shijiazhuang continues to expand and exceeded the average level of the province. Finally, this paper puts forward measures to narrow the income gap between urban and rural residents in Shijiazhuang city.
\end{abstract}

Keywords-Shijiazhuang City; urban and rural residents; income gap, measures

\section{INTRODUCTION}

The report at 18th Party Congress pointed out: "Two structures in urban and rural areas are the main obstacle to the integration of urban and rural areas. We must improve the system and mechanism to form the new relationship between urban and rural areas, promote agriculture by industry, make the city with rural, integrating the urban and rural, allowing farmers to equal participation in the process of modernization to share the achievement of modernization." Shijiazhuang city is the capital of Hebei Province, is located in the south of the province of Hebei, with an area of 15848 square kilometers, with population census of 10163788 people by the end of 2010 year, include the 6 Districts and 12 Counties. In 2012, the city’s GDP totaled 450 billion yuan, per capita gross domestic product was more than $\$ 5000$, urban per capita disposable income was 22998 yuan, farmers per capita net income was 8920 yuan, total revenue was 57.33 billion yuan.

\section{THE CHANGES OF THE INCOME GROWTH RATE AND PER CAPITA INCOME GAP BETWEEN URBAN AND RURAL RESIDENTS IN SHIJIAZHUANG CITY}

Table I shows the per capita income and its growth rate of urban and rural residents in Shijiazhuang city in recent years. In 2001, Shijiazhuang per capita disposable income of urban residents was 6801 yuan. In 2012, per capita disposable income of urban residents was 22998 yuan. The growth amounted to 16197 yuan, with an average annual growth rate of $11.2 \%$; In 2001 , the per capita net income of rural residents was 3149 yuan. In 2012, it increased to 8920 yuan. The growth amounted to 10422 yuan, with an average annual growth rate of $9.15 \%$. In the comparison between urban and rural areas, urban residents' income grew faster than rural residents, the per capita income of rural residents in 2012 roughly equivalent to that of urban residents in 2004. From 2001 to 2012, the absolutely difference of per capita income of urban and rural residents is increasing from 3656 yuan in 2001 to 14078 yuan in 2012.

TABLE I. URBAN AND RURAL RESIDENTS’ PER CAPITA INCOME LEVELS DURING 2001-2012.

\begin{tabular}{|c|c|c|c|c|c|}
\hline \multirow[b]{2}{*}{ Year } & \multicolumn{2}{|c|}{ Urban Residents } & \multicolumn{2}{|c|}{ Rural Residents } & \multirow[b]{2}{*}{$\begin{array}{c}\text { The } \\
\text { Difference } \\
\text { in Income } \\
\text { (yuan) }\end{array}$} \\
\hline & $\begin{array}{l}\text { The per } \\
\text { Capita } \\
\text { Disposable } \\
\text { Income } \\
\text { (yuan) }\end{array}$ & $\begin{array}{c}\text { Growth } \\
\text { Rate }\end{array}$ & $\begin{array}{l}\text { The per } \\
\text { Capita } \\
\text { Net } \\
\text { Income } \\
\text { (yuan) }\end{array}$ & $\begin{array}{c}\text { Growth } \\
\text { Rate }\end{array}$ & \\
\hline 2001 & 6805 & $5.62 \%$ & 3149 & $-0.28 \%$ & 3656 \\
\hline 2002 & 7240 & $6.39 \%$ & 3245 & $3.05 \%$ & 3995 \\
\hline 2003 & 7741 & $6.92 \%$ & 3394 & $4.59 \%$ & 4347 \\
\hline 2004 & 8622 & $11.46 \%$ & 3799 & $11.93 \%$ & 4829 \\
\hline 2005 & 10040 & $16.37 \%$ & 4118 & $8.40 \%$ & 5922 \\
\hline 2006 & 11495 & $14.49 \%$ & 4456 & $8.21 \%$ & 7039 \\
\hline 2007 & 13204 & $14.87 \%$ & 4954 & $11.18 \%$ & 8250 \\
\hline 2008 & 15062 & $14.07 \%$ & 5469 & $10.40 \%$ & 9593 \\
\hline 2009 & 16607 & $10.26 \%$ & 5977 & $9.29 \%$ & 10630 \\
\hline 2010 & 18290 & $10.13 \%$ & 6577 & $10.04 \%$ & 11713 \\
\hline 2011 & 20534 & $12.27 \%$ & 7822 & $18.93 \%$ & 12712 \\
\hline 2012 & 22998 & $12 \%$ & 8920 & $14.04 \%$ & 14078 \\
\hline $\begin{array}{c}\text { The } \\
\text { average }\end{array}$ & 13220 & $11.2 \%$ & 5157 & $9.15 \%$ & 82686 \\
\hline
\end{tabular}

III. THE HISTORICAL TRAJECTORY OF THE INCOME GAP BETWEEN URBAN AND RURAL RESIDENTS IN SHIJIAZHUANG CITY

The first stage: the widening gap between urban and rural stage (1985-1993). In 1984, the third plenary session of the communist party of China passed the "decision on reform the economic system," the focus of the economic system reform started from rural to urban, urban reforms gradually, which marked the beginning reform from rural to urban areas. The main implementation mechanism can be summarized as three kinds of city biased system: system of state monopoly for purchase and marketing of agricultural products, the people's commune system and 
the household registration system. Especially in the stateowned enterprise reform, mobilizing the enthusiasm of the staff and workers of the enterprises, getting rapid release the productivity of the state-owned enterprises that were bound in the traditional economy, and the income of urban workers began to rise. Because of the introduction of city biased policy, so that the income of rural residents is very sole, basically only a source for the agricultural income. This set of policy and system make the city to effectively lower the price of agricultural products, and strictly control the production factors especially the labor flow, the result is that the product market and factor market were distorted, and formed an inclined to city residents. At the same time, because of the agricultural industrial structure didn't make adjustments in time according to the need of the market, resulting the farmers' income growth slowed down, leading to the gap between urban and rural areas expanded rapidly during this period.

The second stage: the gap between urban and rural areas greatly reduced stage (1994-1996). In these 3 years, there has been a noticeable decline in the gap between urban and rural areas of Shijiazhuang city. During this period, due to the rising price of agricultural products, and for government support and encourage, quantity of farmers went out to work, so that the income of migrant workers increase.

The third stage: the gap between urban and rural areas is widening (1997-2010). In this 13 years, the gap between urban and rural areas of Shijiazhuang city gradually widening, slightly only in 2000 and 2004 . During this period, because of two consecutive lower purchase price of grain by the nation, food supply appeared oversupply situation, the situation of increasing output without increasing income was in general, which serious hit the enthusiasm of farmers, and over the same period, agriculture and non-agriculture income also reduced, so that causing farmers revenues, income gap between urban and rural were began to increase.

The fourth stage: in 2012, the gap between urban and rural areas in Shijiazhuang city has narrowed. This is the first time during 13 years for the urban and rural income gap ratio declined greatly, this situation will or will not continue, it is not known. The growth of farmers' income is the main reason. Multi factors including policy subsidies, agricultural prices, labor income growth, all these pulled together the results. Experts said, in recent years, the wage income will become the biggest contribution to the rapid growth of farmers' income.

\section{COMPARISON}

The first, from 2005 to 2010, the income gap between urban and rural residents in Shijiazhuang showed a general widening trend, but the gap narrowed in 2011 for the first time; second, the income gap between urban and rural residents in Shijiazhuang is significantly less than the national average level, which means the income gap between urban and rural areas in Shijiazhuang City is still relatively small compared to the nation; Third, as the capital city of Hebei Province, the income gap between urban and rural in Shijiazhuang city is higher than the average level of Hebei province. Before 2007, the income gap was smaller in Shijiazhuang, after 2007, the income gap between urban and rural residents in Shijiazhuang continues to expand, and more than the province's average level.

\section{THE COUNTERMEASURES}

\section{A. Adjust the Structure and Promote Increasing Production Efficiency}

The important part of the income of the farmers is from agricultural production. In order to improve agricultural efficiency, we must continue to increase the agricultural industrial restructuring and optimizing the industrial layout to realize the prominent agricultural production. The first is to adjust the agricultural structure and promote industrial upgrading. According to the local natural and economic conditions, identify the industry positioning suit to local conditions, reasonable adjust agriculture, forestry and animal husbandry according to the principle of "high-quality, efficient and safe," promote industrial upgrading and increase aquaculture development to improve the proportion of animal husbandry; On the premise of food safety in production, timely adjust the planting structure, increase the proportion of efficient economy crop production to improve the planting benefit; Based on the stability of vegetable production, vigorously develop the sunlight greenhouse as the main facility in production and continuously improve the production level and the proportion of vegetable. The second is to optimize breed structure and quality structure, accelerate improving varieties and improving the quality of agricultural products. We should be based on local advantages and market oriented economy, making the progress of science and technology throughout the whole process of agricultural structure adjustment. Optimize the varieties of products and develop regional characteristic agriculture to form the unique industrial belt or industrial group. The third to suit one's measures to local conditions and optimize the regional industrial layout. According to the comparative advantages in resources, form agricultural production base that has the different characteristics, with the "characteristics" and "excellent" to achieve agricultural efficiency. Promote the development of characteristic industry of the "one countryside one industry" and "one village one product." Accelerate the construction of regional characteristics in pollution-free vegetables, eggs, milk and pear etc. promote characteristic advantage leading industry to form product brand, quality assurance and scale management pattern.

\section{B. Promote Two-way Flow of Production Factors between Urban and Rural Areas}

We should promote the balanced allocation of public resources between urban and rural areas to narrow the gap between urban and rural areas. Doing efforts to promote 
the free flow of production factors between urban and rural areas is very important. You can take the following measures to promote two-way flow of factors of production between urban and rural areas: First, deepen the reform of the land system. The farmer should have the right to use homestead for a long time, and should be protected in law. The right can be transferred through voluntary, equality and paid so that other investors can safely invest. In order to promote capital inflows in rural areas, we should increase the investment on the rural. Second, increase the coverage of rural social security to avoid talent out flow the areal because of welfare problems. Third, to develop rural modernization by establishing agricultural companies, focus on the development of rural characteristic industry, cultural attractions, scenic spots, and to create convenient transportation of the modernization for the rural.

\section{Focus on the Development of County Economy}

According to the actual situation of 17 Shijiazhuang County (city) and its different external environment, we should make the different mode of development for these counties. Based on the potential of county resources, increase the investment on county that develop slow so that balance the difference between counties. County economy is an important condition for increasing the income of farmers. One is to promote technological progress of enterprises, give full play to the leading role of scientific research base, and actively introduce advanced technology, to provide technical support for the development of enterprises; the second is to policy oriented, the government should give policy support in the financial, industrial and commercial, taxation and other aspects. To create good, easy development environment for enterprises, encourage the private capital for the development of characteristic industry, to help enterprises solve the financing problem; the third is to adhere to the market to lead the development of the county economy in industrial development. In addition to government banned or restricted strict management industry, more and more industrial planning should locate the direction of industrial development according to the foundation of the county industrial development and regional advantages.
Develop and support key industries and strive to form the regional characteristics

\section{Protect the Land Rights of Farmers}

Each county in Shijiazhuang city should make efforts to realize fairness allocation of value-added income in the land expropriation process, give farmers compensation according to the regulations, so that the farmers can get the land value-added income. Do efforts to create jobs for surplus labor to solve the problem of unemployment farmers because of land requisition, promote the transfer of farmers from the first industry to urban residents. Improve the compensation standards of the land acquisition, narrowing the scope of land requisition, to establish the mode of land expropriation in line with market economy rules and requirements. The land should be strictly limited in the public area, take the market price as the standard of land compensation. To adapt to the requirements of the rule of law, strengthening the legal construction of the land expropriation system, guarantee the farmers on the land has requisition right to participate, to establish effective mechanism for handling disputes.

\section{ACKNOWLEDGMENTS}

The research work was supported by Social Science Development Research Project of Hebei Provincial under Grant No. 2014021411.

\section{REFERENCES}

[1] Zheng Qunfeng, Research on differences between urban and rural investment in China from the perspective of the income gap. Financial and Teaching, 2010.

[2] Liu Sihe, Factors for influencing the income gap between urban and rural residents in Chongqing. Southwestern University, 2011.

[3] Hong Jie, The income gap between urban and rural residents in Henan Province. Beijing: Jiaotong University, 2011.

[4] Yuan Jinwang, Study on narrowing the income gap between residents in our country at present stage. Ocean University of China, 2011.

[5] Shan Qibao, The urban-rural income gap: The degree and influence factors. Shanxi University of Finance and Economics, 2010.

[6] Han Dan, The income gap between urban and rural residents in Liaoning Province. Liaoning University, 2011. 